Pak. j. sci. ind. res. Ser. A: phys. sci. 2019 62A(1) 57-66

\title{
A Low-Cost Wastewater Treatment Unit for Reducing the Usage of Fresh Water at Car Wash Stations in Pakistan
}

\author{
Naveed ul Hasan Syed ${ }^{a}$, Jamil Ahmad ${ }^{\mathrm{a}}$, Naseer Ahmed Khan ${ }^{\mathrm{a}}$, \\ Nasir Khan ${ }^{b}$ and Muhammad Abid Shafiq ${ }^{a}$ \\ ${ }^{a}$ Department of Chemical Engineering, University of Engineering \& Technology-Peshawar, KPK, Pakistan \\ ${ }^{b}$ Department of Petroleum and Gas Engineering, Balochistan University of Information Technology, \\ Engineering and Managment Sciences (BUITEMS) Quetta, Pakistan
}

(received May 28, 2018; revised August 20, 2018; accepted August 28, 2018)

\begin{abstract}
In this study, a careful survey was conducted at twenty-nine different car-wash stations in Peshawar city to collect wastewater samples and evaluate the usage of fresh water in those stations. Experiments were carried out on a prototype treatment unit comprising sedimentation and filtration. After treatment, the TSS reduced from 1000 to $200 \mathrm{mg} / \mathrm{L}$, hardness 321.60 to $120 \mathrm{mg} / \mathrm{L}$ and turbidity 253 to $3.70 \mathrm{NTU}$, TDS 591 to $400 \mathrm{mg} / \mathrm{L}$ and oil contents 27 to $14 \mathrm{mg} / \mathrm{L}$. The quality of treated water was found suitable for car washing again. Furthermore, a design and cost estimation of a commercial scale low-cost wastewater treatment unit has been provided. It was found that the installation of low-cost wastewater treatment units can save $12 \mathrm{~m}^{3} /$ day of fresh water in a carwash station.
\end{abstract}

Keywords: carwash station, filtration; recycling, sedimentation, wastewater treatment

\section{Introduction}

The availability of adequate quantity of potable water is a major global concern (Norton-Brandao et al., 2013; Qureshi et al., 2013; Zeng et al., 2013; Schwerdtner et al., 2012; Ahmad and El-dessouky, 2008; Eldessouky and Ettouney, 2002). Increased population and unprecedented industrial growth has reduced both the quantity and quality of fresh water, required for domestic, irrigation and industrial use, to an alarming level in different parts of the world (Zeng et al., 2013; Vorosmarty et al., 2010; Oki and Kanae, 2006; Eldessouky and Ettouney, 2002; Vorosmarty et al., 2000). Similarly, in Pakistan many cities are facing severe water shortage problems. Asian Development Bank (ADB) has given a report according to which Pakistan was declared among the water stressed communities and is not able to conserve 80 percent of its water needed for the agricultural, domestic and industrial users (Khair et al., 2012; Ahmad, 2007). Lack of awareness and inadequate practices for water conservation, recycling and reuse contribute more towards water scarcity problems (Khan et al., 2016; Khair et al., 2012; Ahmad, 2011).

Pakistan is passing through a transition phase of political stability, industrial development, improved living standards and resolving power generation issues. These

*Author for correspondence;

E-mail: syednaveed@uetpeshawar.edu.pk factors are also contributing directly and indirectly towards water consumption issues. Specifically speaking about the urban areas, the number of private cars and other transportation vehicles, such as vans, rickshaws, buses and trucks has increased drastically during the last two decades. Due to increase in the number of cars and other vehicles, many car-wash stations, mainly owned by private small-scale investors have started to operate in the country. These carwash stations are consuming large quantity of fresh water without following any water conservation and treatment practices.

Car-wash stations have taken the shape of an industry and the amount of water consumed for washing a car may vary from $0.15 \mathrm{~m}^{3}(150 \mathrm{~L})$ to $0.60 \mathrm{~m}^{3}(600 \mathrm{~L})$ (Lau et al., 2013; Zaneti et al., 2011; Al-Odwani et al., 2007; Karakulski and Morawsk, 2003). Literature suggests that car-wash industry is not only wasting large amount of fresh water but is also abating the quality of water. Wastewater from carwash stations contains harmful pollutants including surfactants, petroleum products, such as oil contents, grease, waxes and different kinds of suspended and dissolved solids (Khan et al., 2016; Lau et al., 2013; Zaneti et al., 2011; Boussu et al., 2007; Al-Odwani et al., 2007; Karakulski and Morawsk, 2003). Any treatment of wastewater in car-wash stations is beneficial for the environment and population in general would be an important step towards a viable future of carwash industry (Lau et al., 2013; Zaneti 
et al., 2011; Al-Odwani et al., 2007; Boussu et al., 2007). At present there are few good examples of water recycling and reuse in Queensland, Australia, where it is mandatory to use $0.07 \mathrm{~m}^{3}(70 \mathrm{~L})$ of reclaimed water for each wash (Zaneti et al., 2011; Panizza and Cerisola, 2010; Boussu et al., 2007). Similarly, many European countries have imposed strict regulations on using fresh water in car-wash stations (Lau et al., 2013; Zaneti et al., 2012, 2011; Panizza and Cerisola, 2010; Boussu et al., 2007; Al-Odwani et al., 2007; Karakulski and Morawsk, 2003).

Al-Odwani (2007) performed a study on water reclamation in 140 commercial car-wash stations in Kuwait, where total water consumption was about 2.5 million gal/day for washing approximately 25,200 cars on daily basis. The authors proposed that $75 \%$ of recycled water along with $25 \%$ of fresh water can be used to wash the cars. In another study, Zaneti et al. (2012; 2011) proposed flocculation-column flotation, sand filtration and chlorination processes for cleaning used water from car-wash stations. Similarly, Karakulski and Morawsk (2003) and Lau et al. (2013) used ultrafiltration and nano-filtration processes to upgrade the quality of car-wash wastewater. Recently, Pinto et al. (2017) and Ucar (2018) studied the possible treatment of car-wash wastewater using membrane filtration processes. The authors found significant improvement in the quality of treated water, however, the application of membrane filtration processes increased the overall operation cost of the wastewater treatment systems.

The literature suggests the work done in the areas of carwash wastewater treatment, recycling and reuse is sparse as compared to the studies carried out on industrial wastewater treatment processes. Similarly, the treatment processes developed for the car-wash industry are either very difficult to implement on commercial scale or expensive to be attracted by the small-scale investors. The main aim of this research work is to propose a lowcost car-wash wastewater treatment unit that can treat and improve the quality of wastewater to an acceptable level that can be reused for washing the cars. The lowcost system should be such that it is easily operatable and acceptable to the investors. It is also important to realize that majority of the middle and small-scale investors are unaware with the importance of wastewater treatment and water conservation practices. These investors mainly focus on their profits and it is difficult for them to accept any extra cost that benefits the environment and public in general. In such circumstances, it is essential to introduce a low-cost wastewater treatment technology to initially attract the investors. Such steps would help the people associated with carwash industry to adapt and realize the importance of wastewater treatment methods. It is also important to note that the wastewater treatment methods are not a source of profit initially. However, in the long run, these methods could be beneficial as the price of tap water is increasing continuously due to decrease in the supply of fresh water and water scarcity issues. The electricity rates are also increasing which would increase the cost of water obtained through borings.

Low-cost wastewater treatment technologies have been utilized for treatment, recycling and reuse of laundry waste and urban wastewater for irrigation purposes (Norton-Brandao et al., 2013; Ahmad and El-dessouky, 2008). Likewise, in this paper, we have proposed a lowcost wastewater treatment unit based on sedimentation and filtration for recycling and reusing the car-wash wastewater. Hence, a lab scale wastewater treatment unit was designed and fabricated to treat and reduce the contaminants such as total suspended solids (TSS), total dissolved solids (TDS), hardness, $\mathrm{pH}$, turbidity and oil contents in the car-wash wastewater. Moreover, a preliminary design and cost estimate of a commercial car-wash wastewater treatment unit is also provided in this research paper. The outcomes of this research work would deliver numerous benefits to Pakistan in the areas of water conservation and wastewater treatment, and would also be applicable to the car-wash industry in other developing countries.

\section{Materials and Methods}

There is no authentic data to report the actual number of car-wash stations and the amount of water consumed in Pakistan. However, it is our general observation that thousands of car-wash stations are operating in the country. In this research work, a survey was conducted in the city of Peshawar, the capital of the province Khyber Pakhtunkhwa (KP), Pakistan. Peshawar is the fifth largest city of Pakistan with its population approximately 3.3 million. The annual population growth rate in the city of Peshawar is $1.4 \%$ and this high rate of increase in population has significantly affected the availability of water for domestic, industrial, and agriculture needs (Tamana et al., 2014; Khan et al., 2010). During the survey, twenty-nine car-wash stations at different locations of Peshawar city were visited to 
collect the wastewater samples, estimate the number of vehicles washed and the amount of water consumed in these car-wash stations. These 29 car-wash stations were selected in such a way to consider them as a representative sample and the wastewater collected during the survey as indicative of the car-wash stations in Peshawar in general. Nevertheless, the actual number of car-wash stations in Peshawar city is much more than twenty-nine. The car-wash stations visited during the survey are listed in Table 1.

The water flowrate from the pipe used to wash the cars in the car-wash stations was $0.0005 \mathrm{~m}^{3} / \mathrm{s}$. The workers spent approximately fifteen minutes on one car during washing i.e. spraying water on the car. So, on an average, every service station nearly consumed $0.45 \mathrm{~m}^{3}(450 \mathrm{~L})$ of water on one car. This gives a total consumption of $351.30 \mathrm{~m}^{3} /$ day $(351,300 \mathrm{~L} /$ day $)$ of water in 29 car wash stations of Peshawar city, as shown in Table 1. For 300 working days in a year, the annual consumption of water becomes 105,390 m³/year (approx. 105 million L/year) in 29 car-wash stations of Peshawar.

If it is assumed that the total number of car-wash stations in Peshawar city is around 80 and the average consumption of water in one car wash station is about $12 \mathrm{~m}^{3} /$ day $(12,000 \mathrm{~L} /$ day) (by considering the data provided in Table 1), then the total amount of water consumed in

Table 1. Car-wash stations visited in the Peshawar city and their daily water consumption

\begin{tabular}{|c|c|c|c|}
\hline Car-wash stations & Address / Location & $\begin{array}{l}\text { Number } \\
\text { of cars } \\
\text { washed } \\
\text { per day }\end{array}$ & $\begin{array}{l}\text { Total } \\
\text { consumption } \\
\text { of water } \\
\text { (L/day) }\end{array}$ \\
\hline Union $\mathrm{CNG}$ & Firdousabad, Jamrod road, Peshawar & 25 & 11.25 \\
\hline Umarzai CNG & Charsadda road, Peshawar & 30 & 13.50 \\
\hline Hastnagar CNG Filling Station & Near Chouti pul, Charsadda road, Peshawar & 35 & 15.75 \\
\hline Yassrab CNG Filling Station & Mouza kandi akhund Ahmed, Ring road, Peshawar & 20 & 9.0 \\
\hline HDIP ServiceStation & Plot \# 2A, Phase V, Hayatabad, Peshawar & 20 & 9.0 \\
\hline Abaseen $\mathrm{CNG}$ & Thumbowano chowk, Jamrod road Peshawar & 30 & 13.50 \\
\hline A.R.G. CNG & Admore A.R.G petroleum haji camp G.T. road, Peshawar & 15 & 6.75 \\
\hline Bangash CNG & Toda near shalan bridge charsadda road, Peshawar & 20 & 9.0 \\
\hline Khan CNG Station & Arbab road, university town, Peshawar & 25 & 11.25 \\
\hline Luqman Shah Enterprises & GT road, Peshawar & 15 & 6.75 \\
\hline Auto Fuels & Khyber Road, Peshawar & 15 & 6.75 \\
\hline Gas Zone & University town chowk, Jamrud road, Peshawar & 10 & 4.50 \\
\hline Khyber CNG & Phase II Hayat abad jamrud road, Peshawar & 25 & 11.25 \\
\hline Gap Enterprises & Thekal payan, jamrud road, Peshawar & 20 & 9.0 \\
\hline Auto Gas Masters & Kohat road Murshid abad, Peshawar & 15 & 6.75 \\
\hline Malik Enterprises & $\begin{array}{l}\text { Shell outlet, Garrison filling station, Jamrud road, } \\
\text { Peshawar }\end{array}$ & 20 & 9.0 \\
\hline Gas Power Ltd CNG Station & PSO outlet, Qila Bala hisar, Peshawar & 25 & 11.25 \\
\hline Azad CNG Station & Main charsadda road, Nishat mills, Peshawar & 35 & 15.75 \\
\hline Falcon CNG Station & Charsadda road, Peshawar & 50 & 22.50 \\
\hline Rapid Service Station & $\begin{array}{l}\text { Mohalla Islamabad, O/STTC Lahore gate main gulbahar } \\
\text { road Peshawar }\end{array}$ & 40 & 18.0 \\
\hline Speed Zone CNG & $\begin{array}{l}\text { Gulababad, opp. hayat abad township, main jamrud road } \\
\text { Peshawar }\end{array}$ & 30 & 13.50 \\
\hline Shah-3 CNG Station & Phase-III Hayat abad, Peshawar & 35 & 15.75 \\
\hline Continental CNG F/S & Opposite defense colony, Khyber road, Peshawar Cantt & 60 & 27.0 \\
\hline Cantt CNG Filling Station & Batti chowk, Jamrud road, Peshawar & 50 & 22.50 \\
\hline Friends CNG Station & Main jamrud road, Peshawar & 15 & 6.75 \\
\hline National CNG Filling Station & Thekal payan, Peshawar & 20 & 9.0 \\
\hline New Abbasin CNG Station & Dalazak road opposite city railway station & 25 & 11.25 \\
\hline Liaqat motors Service Station & Tehkaal road, university town, Peshawar & 20 & 9.0 \\
\hline \multirow[t]{2}{*}{ FC Service Station } & Sadder road, near FC chock, Peshawar cantt & 35 & 16.0 \\
\hline & & $\begin{array}{l}\text { Total } \\
\text { consumption }\end{array}$ & $\begin{array}{l}351.30 \mathrm{~m}^{3} / \text { day } \\
(351,300 \mathrm{~L} / \text { day })\end{array}$ \\
\hline
\end{tabular}


the car-wash stations of the Peshawar becomes 960 $\mathrm{m}^{3} /$ day, which becomes $288,000 \mathrm{~m}^{3} /$ year $(288$ million $\mathrm{L} /$ year). This shows that a large amount of fresh water is consumed and contaminated in car-wash stations. Thus, any implementation of a wastewater treatment system in car-wash stations will save significant amount of fresh water for the community and will also reduce water pollution.

Lab scale wastewater treatment unit. A laboratory scale wastewater treatment unit based on sedimentation and filtration was designed and fabricated in the lab, Fig. 1. The sedimentation and filtration processes can reduce the TSS and turbidity in wastewater to an acceptable level, however, reducing TDS, COD and BOD to an acceptable level or tap water standard needs expensive methods, such as reverse osmosis (RO) or electro dialysis (Ahmad et al., 2008). Similarly, complete removal of oil is not possible with just sedimentation and filtration and requires other methods to remove oil contents, such as installation of oleophillic media separator somewhere after the sedimentation tank. This however, was not possible because using an expensive treatment method may increase the capital cost of the wastewater treatment system. On the other hand, a very high quality treated water was not required for washing the cars. So, we kept our focus on developing a lowcost wastewater treatment unit.

The lab scale wastewater treatment unit consisted of an upper and a lower zone. Two storage tanks of $1 \mathrm{~m} \times 1$ $\mathrm{m}$ each were installed in the lower zone of the unit. One storage tank was used for storing wastewater collected from the car-wash station and was termed as sedimentation tank. The second storage tank was used for collecting treated water obtained after filtration and was termed as product tank. The upper zone consisted

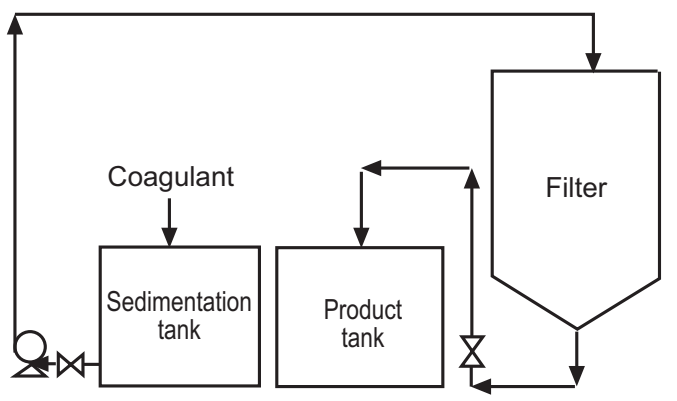

Fig. 1. Schematic diagram of Lab scale car-wash wastewater treatment unit. of a pump and a filter. A pump of $0.25 \mathrm{hp}$ was installed to transfer wastewater from sedimentation tank to filter.

A small filter comprising $0.5 \mathrm{~m}$ bed containing sand and gravels was the main treatment unit, shown in Fig. 2. The filter consisted of four layers made up of sand and gravel. The first layer from the top was gravel, the second and third layers were sand and the bottom layer was gravel. The depth of upper layer in the filter was $0.1 \mathrm{~m}$ and consisted of gravel of particle size $0.00032 \mathrm{~m}$. The second and third layers consisted of sand particles of sizes $0.0005 \mathrm{~m}$ and $0.0010 \mathrm{~m}$, respectively, each one with a depth of $0.15 \mathrm{~m}$. Similarly, the bottom layer consisted of gravel with particle size $0.00064 \mathrm{~m}$ and depth $0.1 \mathrm{~m}$.

The wastewater when flows through the filter takes time to pass through it due to filter bed and there is always a possibility of wastewater accumulation at the top of the filter. Therefore, to maintain an adequate level of wastewater at the top of the filter and to avoid any overflow, an allowance of $0.25 \mathrm{~m}$ was kept for water accumulation above the first layer of the filter. The water level was controlled by a control system, through which the pump automatically turns on or off depending on the level of wastewater above the filter bed. A back-washing facility for filter was also provided represented by the dashed lines in Fig. 2.



Fig. 2. Laboratory scale sand and gravel filter. 


\section{Results and Discussion}

Laboratory analysis of wastewater samples. Wastewater samples from the car-wash stations were collected during the survey and analyzed in the laboratory to check the level of $\mathrm{pH}$, alkalinity, turbidity, TSS, TDS, hardness and oil contents. The results were compared with the tap water standards to examine the contamination level in the wastewater samples. Table 2 shows the comparison of analysis of wastewater and tap water samples, and shows that the amount of contaminations in the wastewater samples is well above the tap water standards. The amount of hardness, turbidity, TSS and TDS in the wastewater sample was very high due to the dust on the cars and washing with soap / detergents. Similarly, oil contents were also found in the wastewater sample, which could be due to lubricants used in different parts of the cars and other vehicles. The samples taken from different car-wash stations were analyzed and it was found that the type and quantity of impurities in all the samples were almost similar. Therefore, wastewater sample of one car-wash station was selected as a basis for our experiments and calculations.

Coagulation. Wastewater sample collected from carwash station was first kept in a sedimentation tank for $24 \mathrm{~h}$ to allow large solid particles to settle down. For reducing turbidity, alum was also added as a coagulant in the sedimentation tank. A small test related to study of

Table 2. Test results of tap water and wastewater from a car-wash station

\begin{tabular}{lll}
\hline \hline Tests & Tap water & $\begin{array}{l}\text { Wastewater sample } \\
\text { (before treatment) }\end{array}$ \\
\hline Total solids (mg/L) & 444 & 1591 \\
TSS (mg/L) & 222 & 1000 \\
TDS (mg/L) & 222 & 591 \\
Turbidity NTU & 0.60 & 253 \\
pH & 7.30 & 6.90 \\
Hardness (mg/L) & 140 & 321.60 \\
Alkalinity (mg/L) & 245 & 210 \\
Oil (mg/L) & --- & 27 \\
\hline \hline
\end{tabular}

coagulant dosage and its effects on the turbidity of wastewater samples was also performed. The amount of alum added ranged from 0.10 to $0.35 \mathrm{~g}$ for different tests and are tabulated in Table 3 . The wastewater samples were kept for one hour in beakers to allow settling after the addition of alum. The results showed that addition of alum decreased the turbidity of wastewater samples because coagulants were formed that settled at a higher rate. Moreover, it was also observed that at a certain point, after the addition of $0.30 \mathrm{~g}$ (for the cases tested in the laboratory), the turbidity of the wastewater samples increased again. This shows that, after addition of a certain amount of alum, the alum started acting as a suspended solid and caused turbidity to increase. A detailed study of alum dosage for different wastewater samples can be performed to understand and develop a correlation for optimum alum dosage. However, investigation of optimum dosage of alum to reduce the turbidity of wastewater was not the main aim of this study and could be done in future.

Laboratory analysis of treated water. Wastewater from the sedimentation tank was pumped to the filter and was passed through it. After passing through the filter, the treated water was collected in the product tank. The water samples from the product tank were collected and analyzed. A comparison of the analysis of treated water, wastewater and tap water is provided in Table 4. The results show that contaminants in the car-wash wastewater reduced to an appreciable amount. The total solids reduced from $1591 \mathrm{mg} / \mathrm{L}$ to $600 \mathrm{mg} / \mathrm{L}$, in which TSS reduced to a higher extent from 1000 $\mathrm{mg} / \mathrm{L}$ to $200 \mathrm{mg} / \mathrm{L}$, almost equal to tap water standards, whereas, TDS reduced from $591 \mathrm{ppm}$ to $400 \mathrm{ppm}$. Similarly, turbidity reduced from 253 NTU to 3.70 NTU, hardness from 321.60 to $120 \mathrm{mg} / \mathrm{L}$ and oil contents from $27 \mathrm{mg} / \mathrm{L}$ to an appreciable amount of $14 \mathrm{mg} / \mathrm{L}$. The $\mathrm{pH}$ of treated water increased slightly which shows that the treated water was more alkaline and can be lowered using caustic soda. The treated water was graded as low-grade water and was found suitable for reuse to wash cars and other vehicles.

Table 3. Results for examining minimum coagulant dosage required to reduce maximum turbidity

\begin{tabular}{lllllll}
\hline \hline Description & Beaker(1) & Beaker(2) & Beaker(3) & Beaker(3) & Beaker(4) & Beaker(6) \\
\hline Alum dose (g) & 0.10 & 0.15 & 0.20 & 0.25 & 0.30 & 0.35 \\
Initial turbidity (NTU) & 250 & 250 & 250 & 250 & 250 & 250 \\
Final turbidity (NTU) & 6.70 & 3.10 & 2.90 & 2.50 & 2.30 & 3.0 \\
\hline \hline
\end{tabular}


Table 4. Analysis of car-wash wastewater, treated car wash wastewater and tap water

\begin{tabular}{llll}
\hline \hline Tests & $\begin{array}{l}\text { Wastewater } \\
\text { (before } \\
\text { treatment) }\end{array}$ & $\begin{array}{l}\text { Treated } \\
\text { water }\end{array}$ & $\begin{array}{l}\text { Tap } \\
\text { water }\end{array}$ \\
\hline $\begin{array}{l}\text { Total Solids } \\
(\mathrm{mg} / \mathrm{L})\end{array}$ & 1591 & 600 & 444 \\
TSS (mg/L) & 1000 & 200 & 222 \\
TDS (mg/L) & 591 & 400 & 222 \\
$\begin{array}{l}\text { Turbidity } \\
\text { (NTU) }\end{array}$ & 253 & 3.70 & 0.60 \\
pH & 6.90 & 8.60 & 7.30 \\
$\begin{array}{l}\text { Hardness } \\
(\mathrm{mg} / \mathrm{L})\end{array}$ & 321.60 & 120 & 140 \\
$\begin{array}{l}\text { Alkalinity } \\
(\mathrm{mg} / \mathrm{L})\end{array}$ & 210 & 300 & 245 \\
\begin{tabular}{l} 
Oil (mg/L) \\
\hline \hline
\end{tabular} & 27 & 14 & -- \\
\hline
\end{tabular}

After getting encouraging results from the laboratory scale wastewater treatment unit, a proposal of a lowcost commercial scale car-wash wastewater treatment system has been provided. The operational procedures are also explained in detail for smooth working of the commercial scale wastewater treatment system.

Proposed commercial scale low-cost car wash wastewater treatment unit. The proposed design of a commercial scale low-cost wastewater treatment unit for car-wash stations consists of a sedimentation tank, a sand and gravel filter, a product tank and a pump. The flow diagram of the commercial scale low-cost wastewater treatment process is shown in Fig. 3. The washing station is proposed to be constructed $2 \mathrm{~m}$ above the ground. The space below the car wash room is proposed to be used for sedimentation and is shown as sedimentation tank in the figure. Filtration unit and product tanks are placed above the car wash room along with the fresh water tank. The wastewater from the car wash flows directly to the sedimentation tank via a drainage system. Coagulants could be added at this stage to improve the settling rate of solid particles. A pump is installed to transfer the water from the sedimentation tank to the filter. A rupture disc is provided on the filtration unit to avoid any damage to the unit due to possible vacuum formation. After filtration, the water flows to the product tank from where it is reused for car washing. The wastewater treatment system is designed for treating $24 \mathrm{~m}^{3} /$ day of wastewater, with a point of view that it can accommodate any increase in the number of cars coming for washing in future.
The volume of product tank is $12 \mathrm{~m}^{3}$, whereas the volume of the sedimentation tank is $24.5 \mathrm{~m}^{3}$. This is because, at first, the whole day would take the sedimentation tank to fill with the wastewater from car washing. At the end of the first day when the level of water in the sedimentation tank reaches to a certain level e.g. $90 \%$ the pump will start transferring the wastewater to the filter automatically. When an amount of $12 \mathrm{~m}^{3}$ of water will be treated and sent to the product tank the pump will stop transferring further water to the filter. The next day morning, $12 \mathrm{~m}^{3}$ of treated water will be available to use either directly or mixed with the fresh water for the car wash. This $12 \mathrm{~m}^{3}$ of treated water can last for one day easily, while the rest of 12 $\mathrm{m}^{3}$ of the wastewater from the sedimentation tank will be treated and sent to the product tank during this time. This new treated amount of water is available for the next day or if required on the same day. In this way a continuous cycle will be developed to provide treated water for car washing.

The proposed design described above may be used by those who intend to construct and start a new car wash station where a sufficient land is available to prepare a slope and construct the car wash room $2 \mathrm{~m}$ above the ground. This design is more feasible for the situation where the land is already in slope i.e. hilly or mountain areas. While, for existing car wash stations where the car wash room has already been built at the ground level or if the land is flat and limited, the sedimentation tank is recommended to be constructed underground.



Fig. 3. Commercial scale wastewater treatment system for a car-wash station. 
The wastewater may leak and pose threat to seep below into the drinking water table. Hence, a suitable sealant on the walls and bottom is required which will not significantly increase the capital cost of the treatment system. It is also recommended that the maintenance of the plant is required every 15-20 days for the removal of sludge from the bottom of the sedimentation tank and for backwashing the filter. The process of backwashing has been shown in Fig. 3 with dashed lines. Backwashing of filtration unit is necessary for its efficient performance and can be done via fresh or treated water with a backward flow. In this design, using the treated water for backwashing has been proposed. API separators are also proposed for future extension of the wastewater treatment unit to reduce the oil contents from the wastewater.

Material of construction. The sedimentation tank was proposed to be made up of Reinforced concrete (RCC). The walls and base of the tank were proposed to be 9 inches thick with steel to support heavy load i.e. water level of $24 \mathrm{~m}^{3}$. The top of the sedimentation tank acted as a floor for car washing and accommodated a maximum of 2 cars for which a wall thickness of 6 inches for the floor was considered appropriate.

The filter in the commercial scale wastewater treatment unit consisted of sand and gravel layers, as shown in Fig. 4. The upper layer contained gravel of $0.0032 \mathrm{~m}$ particle size with $0.20 \mathrm{~m}$ depth inside the filtration unit. The second and third layers from the top contained sand each with $0.30 \mathrm{~m}$ depth. In the second layer sand particles of $0.0005 \mathrm{~m}$ and in the third layer sand particle of 0.001 $\mathrm{m}$ size were recommended. The bottom layer consisted of gravel of particles size $0.006 \mathrm{~m}$ with $0.20 \mathrm{~m}$ depth. The area of the filter was taken equal to $1 \mathrm{~m}^{2}$. A depth of $0.50 \mathrm{~m}$ was recommended for avoiding any overflow of the wastewater at the top of the filter.

Cost estimation. A cost estimation of the commercial scale car wash wastewater treatment unit has also been carried out to assess the feasibility of the system. The energy required for the pump and motor to treat $24 \mathrm{~m}^{3} /$ day is shown in Table 5.

Total cost of the treatment unit was evaluated and shown in Table 6. It includes fixed and operating costs per year. Rates of the material were taken as on 25.01.2017. For capital cost $25 \%$ amount was added as tax and contractor profit. Maintenance and labour costs were also included in the operating cost that made it equal to US \$ 953/year. So, the total fixed and the operating costs per year of the proposed commercial scale low cost car wash wastewater treatment unit became US \$ 2677 and US $\$ 1865$, respectively, that makes total capital cost equal to US $\$ 4542$.

To calculate the payback period of the proposed commercial wastewater treatment unit, two cases were considered, presented in Table 7. As mentioned previously, the basis for the total amount of water conserved or treated in one car wash station was taken as $12 \mathrm{~m}^{3} /$ day that becomes $3600 \mathrm{~m}^{3} /$ year. In the first case, the cost of water was taken as US $\$ 2 / \mathrm{m}^{3}$ in which the payback period was 3.5 months. In the second case, the cost of water was taken as US $\$ 1 / \mathrm{m}^{3}$ and the calculated payback period was 7 months.

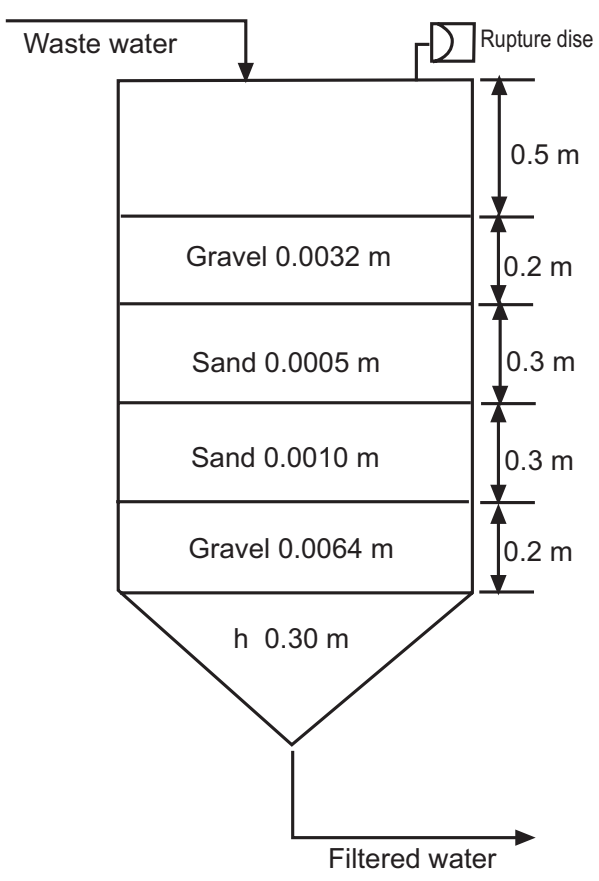

Fig. 4. Sand and gravel filter for commercial scale car-wash wastewater treatment unit.

Table 5. Pump and motor requirement

\begin{tabular}{ll}
\hline \hline Parameters & Value \\
\hline Quantity of wastewater & $12 \mathrm{~m}^{3} /$ day \\
$50 \%$ excess & $24 \mathrm{~m}^{3} /$ day \\
Required pump capacity to discharge 24 & $0.10 \mathrm{~m}^{3} / \mathrm{min}$ \\
$\mathrm{m}^{3} /$ day assuming 4h motor running/day & \\
Head required & $8 \mathrm{~m}$ \\
SG. of wastewater & $\cong 1.0$ \\
Pump efficiency & 0.80 \\
Calculated BHP of pump & $0.218 \cong 0.22$ \\
\hline \hline
\end{tabular}


Table 6. Total cost of the treatment system.

\begin{tabular}{lll}
\hline \hline Material & Quantity & $\begin{array}{l}\text { Total } \\
\text { Cost } \\
\text { (US \$) }\end{array}$ \\
\hline Fixed cost & & \\
Sedimentation tank & 1 & 1041 \\
Storage tank & 1 & 521 \\
Sand and gravel filter & 1 & 66 \\
Housing of filter & 1 & 117 \\
Pipe required 1" & $37 \mathrm{~m}$ & 286 \\
Elbows & 8 & 23 \\
Valves & 9 & 60 \\
Motor and pump 0.25 hp & 1 & 29 \\
Sub total & & 2143 \\
Tax + contractor profit & $@, 25 \%$ & 534 \\
\hline Total fixed cost (a) & & $2677 /$ - \\
\hline Operating cost / Year & & \\
Energy cost normal filtration & $258.40 \mathrm{kwh}$ & 51.60 \\
Energy cost backwashing & $13 \mathrm{kwh}$ & 2.6 \\
Coagulant cost & $2.45 \mathrm{Mton}$ & 858 \\
Maintenance plus labor cost & - & 953 \\
Total operating cost (b) & & $1865 /-$ \\
\hline Total capital cost (a+b) & & $4542 /-$ \\
\hline \hline
\end{tabular}

Table 7. Payback period

\begin{tabular}{ll}
\hline \hline Parameters & Value \\
\hline$\underline{\text { Case 1 }}$ Cost of water & US $\$ 2 / \mathrm{m}^{3}$ \\
Water recycled/saved & $3600 \mathrm{~m}^{3} /$ year \\
Cost of water saved & US $\$ 7200 /$ year \\
Payback period & $=7.5$ months (approx.) \\
Case 2 & US $\$ 1 / \mathrm{m}^{3}$ \\
Cost of water & $3600 \mathrm{~m}^{3} /$ year \\
Water recycled/saved & US $\$ 3600 /$ year \\
Cost of water saved & $=15$ months (approx.) \\
Payback period & \\
\hline \hline
\end{tabular}

\section{Conclusion}

A laboratory scale low-cost wastewater treatment unit based upon sedimentation and filtration has been fabricated to treat the car-wash wastewater and make it suitable for washing the cars again. In this study, 29 car wash stations at different locations of the city were visited and the samples of wastewater were collected. During the visits it was estimated that on average, one car-wash station consumes $0.45 \mathrm{~m}^{3}(450 \mathrm{~L})$ of water on washing one car that makes $12 \mathrm{~m}^{3}(12000 \mathrm{~L})$ for washing 26 cars a day. For 29 car-wash stations the amount of water used for washing cars becomes $351.3 \mathrm{~m}^{3}$ (351,
$300 \mathrm{~L})$ per day. This large amount of fresh water can be saved by implementing low-cost wastewater treatment units in car-wash stations.

The laboratory analysis of wastewater samples showed that the presence of contaminants such as TSS, TDS, turbidity, hardness and oil contents were well above the tap water standards. The wastewater samples were treated in the laboratory scale wastewater treatment unit which reduced TSS from $1000 \mathrm{mg} / \mathrm{L}$ to $200 \mathrm{mg} / \mathrm{L}$, TDS from $591 \mathrm{mg} / \mathrm{L}$ to $400 \mathrm{mg} / \mathrm{L}$, turbidity from $253 \mathrm{NTU}$ to 3.70 NTU. Hardness and oil contents were also reduced to an acceptable value that made the treated water suitable for reuse in car-wash stations.

After achieving promising results with the lab scale treatment unit and realizing the viable applications of the low-cost wastewater treatment units in car-wash stations, a commercial scale low-cost car-wash wastewater treatment unit was proposed. All accessories of the system including pump, motor, sand and gravel filter, piping's and construction material for RCC tanks are locally available. The total capital cost of the proposed unit was US $\$ 4542$, with a payback period of less than one and a half year. In future, the design of the proposed wastewater treatment unit can be improved in terms of automation and optimization of the process. It was also recommended that $70-80 \%$ of treated water along with $20-30 \%$ of fresh water could be used for car-wash. However, if only recycled water is used continuously, then the treated water should be exchanged with fresh water after 3 days.

The benefits and need of wastewater recycling and reuse has already been recognized and adopted all over the world. However, the necessity of putting attention towards wastewater treatment systems for car-wash stations is vital as it is beneficial for the environment and society both. It would be in the interest of the government to impose legislation on the carwash stations to install wastewater treatment units. Given the importance of environmental concerns and water shortage problems, it is imperative that such a policy be implemented in all the car-wash stations in the city of Peshawar and in other cities of Pakistan.

\section{Acknowledgement}

The authors greatly acknowledge the facilities provided by the Department of Chemical Engineering, University 
of Engineering \& Technology, Peshawar, Pakistan during this research work. The authors also acknowledge the assistance provided by Shoukat, Sikander, Siyar and Ejaz.

Conflict of Interest. The authors declare no conflict of interest

\section{References}

Ahmad, B. 2011. Water management-A solution to water scarcity in Pakistan. Journal of Independent Studies and Research-MSSE, 9: 111-125.

Ahmad, J., EL-Dessouky, H.T. 2008. Design of a modified low-cost treatment system for the recycling and reuse of laundry waste water. Resources, Conservation and Recycling, 52: 973-978.

Ahmad, S. 2007. Building high performance knowledge institution for planning of water resources in Balochistan. Project for Supporting Implementation of IWRM Policy in Balochistan - Government of Balochistan $-A D B$ and Royal Government of Netherlands, Water for Balochistan Policy Briefings, vol. 3, No. 4, TA-4560 Pakistan.

Al-Odwani, A., Ahmed, M., Bou-Hamad, S. 2007. Carwash water reclamation in Kuwait. Desalination, 206: $17-28$.

Boussu, K., Kindts, K., Vandecasteele, C., Van der Bruggen, B. 2007. Applicability of nanofiltration in the carwash industry. Separation and Purification Technology, 54: 139-46.

Eldessouky, H.T., Ettouney, H.M. 2002. Fundamentals of Salt Water Desalination, $3^{\text {rd }}$ edition, Elsevier B.V., Netherland.

Karakulski, K., Morawski, A.W. 2003. Treatment of wastewater from wastewater from car washes by ultrafiltration. Fresenius Environment Bulletin, 12: 343-348.

Khair, S.M., Mushtaq, S., Culas, R.J., Hafeez, M. 2012. Groundwater markets under the water scarcity and declining water table conditions: The upland Balochistan Region of Pakistan. Agricultural Systems, 107: 21-32.

Khan, H., Iqbal, F., Saeed, I., Khan, I. 2010. Estimating willingness to pay for improvements in drinking water quality: Evidence from Peshawar, Northern Pakistan. Environmental Economics, 1: 38-43.

Khan, M.M., Zaman, K., Irfan, D., Awan, U., Ali, G., Kyophilavong, P., Shabaz, M., Naseem, I. 2016. Triangular relationship among energy consumption, air pollution and water resources in Pakistan. Journal of Cleaner Production, 112: 1375-1385.

Lau, W.J., Ismail, A.F., Firdaus, S. 2013. Car wash industry in Malaysia: Treatment of car wash effluent using ultrafiltration and nanofiltration membranes. Separation and Purification Technology, 104: 26-31.

Norton-Brandao, D., Scherrenberg, S.M., Van Lier, J.B. 2013. Reclamation of used urban waters for irrigation purposes-A review of treatment technologies. Journal of Environmental Management, 122: 85-98.

Oki, T., Kanae, S. 2006. Global hydrological cycles and world water resources. Science, 313: 10681072.

Panizza, M., Cerisola, G. 2010. Applicability of electrochemical methods to carwash wastewaters for reuse. Part 1: Anodic oxidation with diamond and lead dioxide anodes. Journal of Electro Analytical Chemistry, 638: 28-32.

Pinto, A.C.S., deBarros Grossi, L., deMelo, R.A.C., deAssis, T.M., Ribeiro, V.M., Amaral, M.C.S., deSouza Figueiredo, K. C. 2017. Carwash wastewater treatment by micro and ultrafiltration membranes: effects of geometry, pore size, pressure difference and feed flow rate in transport properties. Journal of Water Process Engineering, 17: 143-148.

Qureshi, M.E., Hanjra, M.A., Ward, J. 2013. Impact of water scarcity in Australia on global food security in an era of climate change. Food Policy, 38: 136-145.

Schwerdtner, M.K., Hussain, S., Ferse, S.C.A., Maria, M.C. 2012. Water scarcity in the Spermonde Archipelago, Sulawesi, Indonesia: Past, present and future. Environmental Science \& Policy, 23: 74-84.

Tamanna, B., Khan, H., Khan, M.A. 2014. Estimation of demand for bottled water in Peshawar-Pakistan (A case study of University campus). Euro-Asian Journal of Economics and Finance, 2: 216-223.

Ucar, D. 2018. Membrane processes for the reuse of car washing wastewater. Journal of Water Reuse and Desalination, 8: 169-175.

Vorosmarty, C.J., Green, P., Salisbury, J., Lammers, R.B. 2000. Global water resources: vulnerability from climate change and population growth. Science, 289: 284-288.

Vorosmarty, C.J., McIntyre, P., Gessner, M.O., Dudgeon, 
D., Prusevich, A., Green, P., Glidden, S., Bunn, S.E., Sullivan, C.A., Liermann, C.R. 2010. Global threats to human water security and river biodiversity. Nature, 467: 555-561.

Zaneti, R., Etchepare, R., Rubio, J. 2012. More environmentally friendly vehicle washes: water reclamation. Journal of Cleaner Production, 37: 115-124.
Zaneti, R., Etchepare, R., Rubio, J. 2011. Car wash wastewater reclamation. Full-scale application and upcoming features. Resources, Conservation and Recycling, 55: 953-959.

Zeng, Z., Liu, J., Savenije, H.H.G. 2013. A simple approach to assess water scarcity integrating water quantity and quality. Ecological Indicators, 34: 441-449. 